\section{Risk factors for healthcare-associated infection in pediatric intensive care units: a systematic review}

\author{
Fatores de risco para infecções associadas aos \\ cuidados de saúde em unidades de terapia \\ intensiva pediátrica: uma revisão sistemática
}

\author{
1 Instituto de Medicina \\ Integral Professor Fernando \\ Figueira, Recife, Brasil. \\ 2 Centro de Pesquisa Aggeu \\ Magalhães, Fundação \\ Oswaldo Cruz, Recife, Brasil. \\ 3 Universidade Federal de \\ Pernambuco, Recife, Brasil. \\ Correspondence \\ M. J. G. Mello \\ Instituto de Medicina \\ Integral Professor Fernando \\ Figueira. \\ Rua dos Coelhos 300, Recife, $P E$ \\ 50070-550, Brasil. \\ jcorreiajmello@gmail.com
}

\begin{abstract}
A systematic review of observational studies on risk factors for healthcare-associated infection in pediatric Intensive Care Units (ICU) was carried out. Studies indexed in MEDLINE, LILACS, Cochrane, BDENF, CAPES databases published in English, French, Spanish or Portuguese between 1987 and 2006 were included and cross references added. Key words for search were "cross in fection" and "Pediatric Intensive Care Units" with others sub-terms included. 11 studies were selected from 419 originally found: four studies had healthcare-associated infection as the main outcome without a specific site; three articles identified factors associated with lower respiratory tract infection (pneumonia or tracheitis); three articles were concerned with laboratoryconfirmed bloodstream infection; and a single retrospective study analyzed urinary tract infection. The production of evidence on risk factors Paediatric ICU has not kept up the same pace of that on adult - there are few studies with adequate design and statistical analysis. The methodological diversity of the studies did not allow for a summarized measurement of risk factors.
\end{abstract}

Cross Infection; Pediatric Intensive Care Units, Delivery of Health Care
Maria Júlia Gonçalves de Mello 1 Maria de Fátima Pessoa Militão de Albuquerque 2,3 Heloísa Ramos Lacerda 3 Wayner Vieira de Souza 2 Jailson B. Correia 1 Murilo Carlos Amorim de Britto ${ }^{1}$

\section{Introduction}

Substantial progress has been made in the surveillance of healthcare-associated infections (HAI), previously known as hospital infections. The identification of risk factors enables the development of preventive strategies 1,2. Although the National Nosocomial Infection Surveillance System (NNIS) was established in 1970 in the United States, it was not until 1987 that Jarvis and colleagues published a study using data from the NNIS, stressing the higher incidence of healthcare-associated infection in children and adolescents as well as differences in the site and microorganisms involved 3. Another ten years went by before the Centers for Disease Control and Prevention (CDC), in cooperation with the National Association of Children's Hospitals and Related Institutions (NACHRI), established the Pediatric Prevention Network (PPN) with the aim of determining the characteristics of hospital infection as well as developing and testing intervention strategies for reducing the occurrence of these events 4

The incidence or prevalence rates of healthcare-associated infections in pediatric Intensive Care Units (ICU) and their sites vary considerably in both individual and multicentric studies, but most authors have progressively adopted the standardized methodology of the NNIS 5,6,7. Although indicators differed according to the type of adult ICU (cardiothoracic, surgical, medical, 
oncology, etc.), the NNIS system did not establish a classification for different types of pediatric ICU. Similarly, information reported on surgical patients in pediatric ICUs used to be combined with data on patients in adult ICUs in this surveillance system ${ }^{8}$. In the NNIS system, data were collected using standardized protocols that relied upon selected procedures such as urinary catheter, central line and ventilator utilization. Despite the advances made with this approach, these studies do not allow the establishment of associations other than those with the selected risk procedures.

Studies carried out to establish predictive models for healthcare-associated infection have investigated risk factors, both intrinsic and extrinsic, either separately or in combination. Intrinsic factors generally include age, gender, nutritional status, underlying disease and severity of the illness. To assess disease severity and to predict the risk of death, scores such as the Paediatric Risk of Mortality (PRISM), or its modified PRISM III version, and the Paediatric Index of Mortality (PIM) or its PIM II modification have been used 9,10,11,12,13,14,15. Extrinsic factors such as aspects of treatment, available structure and the quality of care have been studied as well 16 . These include common invasive procedures (mechanical ventilation, central venous catheter, urinary catheter), the use of medication (antimicrobial agents, immunosuppressors, gastric acid blockers), parenteral nutrition and blood products, for example 14,15 .

A large number of studies have demonstrated associations between different risk factors and healthcare-associated infection in adult ICU. Such studies have been carried out with a certain degree of standardization, which allowed systematic and non-systematic literature reviews to support the production of guidelines $17,18,19,20,21,22,23,24$. However it is inadequate to simply extrapolate data on adult ICU to paediatric ICU, as children are not little adults 25 . Pediatric ICUs are unique entities and require specific prevention and control strategies based on the results of studies carried out locally.

Healthcare-associated infections in paediatric ICUs result in substantial illness, mortality and high costs and requires specific prevention measures. This justifies the present systematic literature review, the aim of which is to describe the variables studied and those identified as risk factors for healthcare-associated infection in pediatric ICUs.

\section{Material and methods}

A protocol for the systematic review was designed based on the recommendations of the Meta-analysis of Observational Studies in Epidemiology (MOOSE) study group 26 and the definitions, outcomes and study eligibility criteria were defined a priori.

Observational cohort or case-control studies published between 1987 and 2006 in English, French, Spanish or Portuguese investigating healthcare-associated infection as an outcome in children or adolescents (from one month to 12 years old) in paediatric ICUs were included Healthcare-associated infection and its specific infection sites were defined by the CDC criteria There are specific criteria only for children $\leq 12$ months 5,6,7.

As part of the search strategy, we conducted searches on MEDLINE, LILACS, Cochrane and BDENF (Nursing) databases through the Virtual Health Library (http://www.bireme.br/php/index.php). This was complemented by searches on PubMed (http://www.ncbi.nlm.nih.gov/sites/ entrez), as well as the CAPES gateway, which provides access to Masters' Dissertations and doctoral theses produced in Brazil (http://servicos. capes.gov.br/capesdw/). The Medical Subject Headings (MeSH) terms "cross infection" and "intensive care units, paediatric" were used. The term "cross infection" encompasses the following sub-terms: "infection, cross"; "cross infections"; "infections, cross"; "infections, hospital"; "hospital infection"; "infection, hospital”; "hospital infections"; "infections, nosocomial”; "infection, nosocomial"; "nosocomial infection" and "nosocomial infections". The term "intensive care units, paediatric" includes pediatric ICU. Equivalen terms were also searched in the other languages, according to their indexing notes. The following limits were used: humans, english, french, spanish, portuguese, infant: 1-23 months; preschool child; 2-5 years, child; 6-12 years. Reference lists of the articles selected for detailed reading were also hand searched (Figure 1).

After combining the results of all searches and excluding repeated references, abstracts from 402 articles and 17 theses were initially identified to be independently assessed by two of the authors (M. J. G. M. and M. F. P. M. A.) for eligibility for detailed reading. At this stage, intervention studies, studies with inadequate exposure or outcome definitions, and studies on healthcare-associated infection of a viral etiology were excluded. Abstracts for which there was no agreement as to the inclusion were analyzed jointly and the decision was made by consensus. Thus, 84 (80 articles and four theses) were ob- 


\section{Figure 1}

Flowchart of study selection process in the systematic review of risk factors for healthcare-associated infection in pediatric intensive care units.

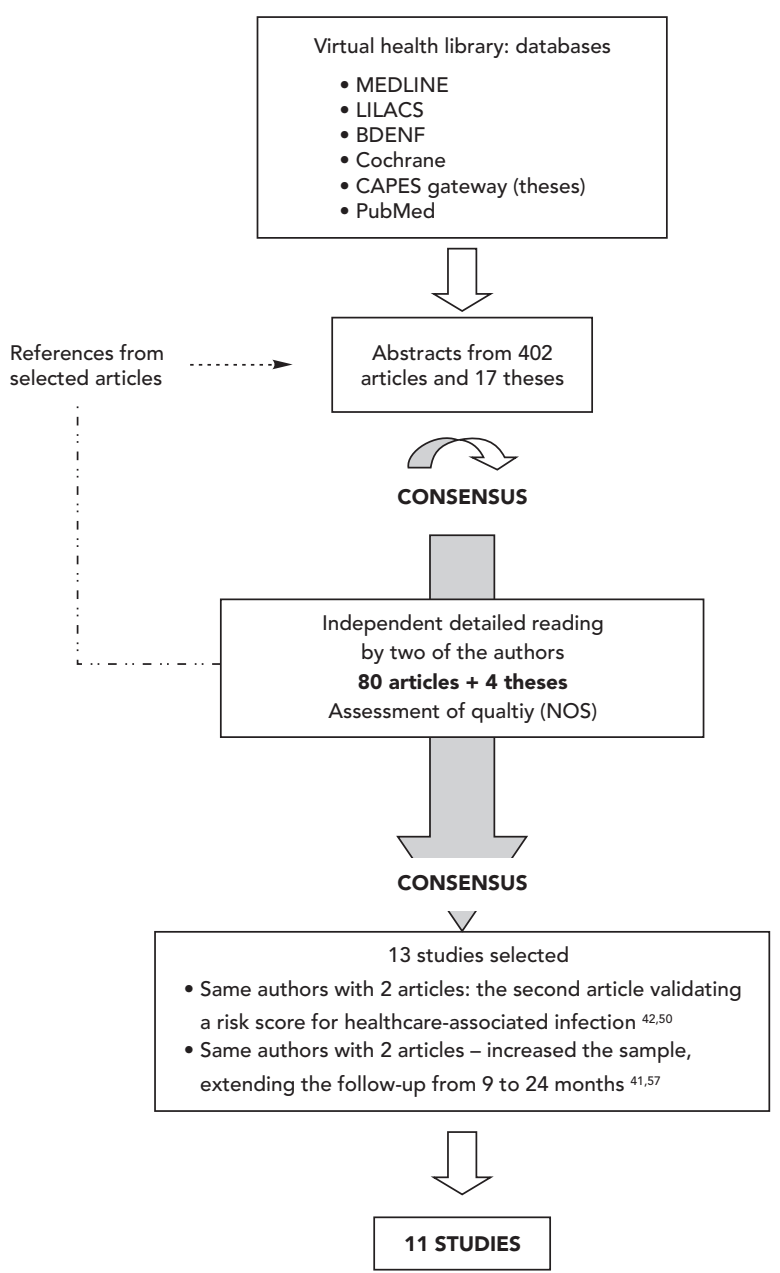

tained for detailed reading by the same two authors independently $27,28,29,30,31,32,33,34,35,36,37,38$ $39,40,41,42,43,44,45,46,47,48,49,50,51,52,53,54,55,56,57,58,59,60$ $61,62,63,64,65,66,67,68,69,70,71,72,73,74,75,76,77,78,79,80,81,82$ $83,84,85,86,87,88,89,90,91,92,93,94,95,96,97,98,99,100,101,102$, $103,104,105,106,107,108,109,110$.

The same authors independently assessed the full papers on the basis of $a$ priori eligibility criteria. Reasons for exclusion at this stage included studies that simultaneously analyzed children and adults 32 , those with no multivariate analysis or with no presentation of association measures $33,34,35$, those in which the outcome was death due to healthcare-associated infection 36 or that reported healthcare-associated infection in paediatric patients analyzing "stay in the pediatric ICU” was one of the risk factors 37,38 . Thirteen papers were selected after consensus, but two of these studies were subsequently excluded, either because the results of the study had already been published on the same population and assessed the same outcome, differing only in sample size 41 , or because the authors performed a randomization of the cases for a validation study of the risk of healthcare-associated infection based on a previously published article 42 .

Data from the final 11 selected studies were extracted into a pre-defined, Microsoft Excel v. 8.0 
(Microsoft Corp., USA) spreadsheet, with the following parameters from each study: design, duration, setting, sample size, age range, main healthcare-associated infection indicators, results of univariate analysis and final model of the multivariate analysis.

Studies were assessed for quality using the "Newcastle-Ottawa Scale" 111 for cohort studies, which includes evaluation of selection (representativeness of exposed subjects, selection of non-exposed subjects, assessment of exposure and outcome not present at the beginning of the study), comparability and outcome (assessment, sufficient follow-up for the outcome to occur and percentage of losses). This scale is recommended by the Cochrane Non-Randomized Studies Methods Working Group available at the electronic address (http://www.ohri.ca/programs/ clinical_epidemiology/oxford.htm).

Although the authors intended to construct a summarized measurement of the association between risk factors and healthcare-associated infection, this was not possible due to the diversity of outcomes and the manner in which the risk factors were defined or categorized.

\section{Results}

\section{Description and quality of studies}

The 11 selected studies included 10 papers published in peer-reviewed journals and one dissertation. Age range was heterogeneous and it was unclear whether some studies included newborns. The upper age limit found was 18 years. In these studies, the main outcomes were hospital infection in any site 50,51,52,54, laboratory-confirmed bloodstream infection 55,56,57, lower respiratory tract infection 58,59,60 and urinary tract infection 49 . All but one article 49 achieved the maximum score of the Newcastle-Ottawa Scale for cohort studies. Table 1 presents the characteristics of the selected studies.

\section{Healthcare-associated infection as outcome}

Four selected studies had healthcare-associated infection without a specific site as the main outcome 50,51,52,54. These reported an incidence of healthcare-associated infection episodes ranging from 10 to $33 \%$. The healthcare-associated infection incidence density (not reported in the study by Singh-Naz et al. ${ }^{50}$ ) ranged from 20.0 to 51.7 per 1,000 patients/days.

Among the intrinsic variables (displayed in Table 2) neither gender nor underlying disease remained associated to healthcare-associated infection in the final model in any of the four studies. Regarding disease severity as assessed by PRISM, Singh-Naz et al. 50 and El-Nawawy et al. 52 found a significant association to healthcare-associated infection (the latter used the PRISM III). Singh-Naz et al. 50 considered the mean PRISM score of the patients for the analysis, whereas Gilio et al. 51, who categorized the scores into fourunit intervals, found no significant association. Being a patient in the post-operative period was a risk factor in the analysis of Singh-Naz et al. 50 and Figueiredo 54 . This variable was not significant in the final model of Gilio et al. 51 and was not studied by El-Nawawy et al. 52 .

Among the extrinsic factors, the time from pediatric ICU admission to the development of healthcare-associated infection was found to be significantly associated to healthcare-associated infection in the studies by Singh-Naz et al. 50 and Gilio et al. 51. El-Nawawy et al. 52, on the other hand, found that healthcare-associated infection was associated to a longer mean length of hospitalization in the pediatric ICU.

The ratio of invasive procedures, defined as the relation between the total utilization time in days of each procedure (central venous catheter, urinary catheter and respirator) and length of stay in the pediatric ICU until healthcare-associated infection diagnosis, was associated to healthcare-associated infection in the studies by Singh-Naz et al. 50 and Gilio et al. 51. In contrast El-Nawawy et al. 52 and Figueiredo 54 did not find a significant association between invasive procedures and HAI.

Parenteral nutrition was a risk factor for HAI in the studies by Singh-Naz et al. 50, Gilio et al. 51 and Figueiredo 54 . This variable was not studied by El-Nawawy et al. 52 .

Antimicrobial therapy and its duration were analyzed by Singh-Naz et al. 50 and Gilio et al. 51 and only in the former a significant association was found. Being admitted to the pediatric ICU being referred from wards other than the emergency room was a risk factor observed by ElNawawy et al. 52 but was not studied by others.

\section{Bloodstream infection as outcome}

Three studies assessed risk factors for bloodstream infection - Laboratory-confirmed bloodstream infection (BSI-LCBI) 55,56,57, two of them included only patients with central venous access 55,56 . The BSI-LCBI rate (Table 1 ) ranged from 4.2 to $9.98 \%$. Table 3 displays the set of variables associated to the outcome. Amongst intrinsic factors, underlying disease and age showed no statistical significance, whereas genetic syndrome remained in the model by Elward et al. 57 . 
Characteristics of the studies included in the systematic review of observational studies on healthcare-associated infection (HAI) in pediatric Intensive Care Units, published between 1987 and 2006.

\begin{tabular}{|c|c|c|c|c|c|c|c|c|c|}
\hline \multirow[t]{3}{*}{ Study } & \multirow[t]{3}{*}{ Year } & \multirow[t]{3}{*}{ Outcome } & \multicolumn{4}{|c|}{ Method } & \multicolumn{3}{|c|}{$\mathrm{HAl}$ indicators } \\
\hline & & & \multirow[t]{2}{*}{ Design } & \multirow{2}{*}{$\begin{array}{l}\text { Year begun *, } \\
\text { duration and } \\
\text { setting }\end{array}$} & \multirow{2}{*}{$\begin{array}{l}\text { Number of } \\
\text { participants }\end{array}$} & \multirow[t]{2}{*}{ Age } & \multicolumn{2}{|c|}{ Accumulated incidence } & \multirow{2}{*}{$\begin{array}{c}\begin{array}{c}\text { Incidence } \\
\text { density \# }\end{array} \\
\mathrm{HAl} / 1,000 \\
\text { patients-day }\end{array}$} \\
\hline & & & & & & & $\begin{array}{l}\text { HAl rate ** } \\
(\mathrm{n})\end{array}$ & $\begin{array}{l}\text { PHAI rate } * * \star \\
\text { (n) }\end{array}$ & \\
\hline $\begin{array}{l}\text { Singh-Naz } \\
\text { et al. } 50\end{array}$ & 1996 & $\mathrm{HAl}$ & $\begin{array}{c}\text { Prospective } \\
\text { cohort }\end{array}$ & $\begin{array}{c}\text { 1992, } 12 \\
\text { months/USA }\end{array}$ & 945 & $\begin{array}{c}\text { Mean in years } \\
\text { with } \mathrm{HAl}=0.6 \\
\text { and without } \\
\mathrm{HAl}=3.5\end{array}$ & $10.2(96)$ & $7.93(75)$ & - \\
\hline $\begin{array}{l}\text { Gilio } \\
\text { et al. } 51\end{array}$ & 2000 & $\mathrm{HAl}$ & $\begin{array}{c}\text { Prospective } \\
\text { cohort }\end{array}$ & $\begin{array}{c}\text { 1994, } 25 \\
\text { months/Brazil }\end{array}$ & 500 & $\begin{array}{l}28 \text { days to } 192 \\
\text { months }\end{array}$ & $13.0(65)$ & $9.2(46)$ & 31.7 \\
\hline $\begin{array}{l}\text { Figueiredo } \\
54\end{array}$ & 2002 & $\mathrm{HAl}$ & $\begin{array}{l}\text { Ambi- } \\
\text { directional } \\
\text { cohort }\end{array}$ & $\begin{array}{c}\text { 1997, } 45 \\
\text { months/Brazil }\end{array}$ & 425 & $\begin{array}{l}28 \text { days to } 36 \\
\text { months }\end{array}$ & 33.4 (142) & 33.4 (142) & 51.7 \\
\hline $\begin{array}{l}\text { El-Nawawy } \\
\text { et al. } 52\end{array}$ & 2006 & $\mathrm{HAl}$ & $\begin{array}{c}\text { Prospective } \\
\text { cohort }\end{array}$ & $\begin{array}{c}\text { 2003, } 12 \\
\text { months/Egypt }\end{array}$ & 216 & 1 to 46 months & $29.6(64)$ & $23.14(50)$ & 40.0 \\
\hline \multirow[t]{4}{*}{$\begin{array}{l}\text { Odetola } \\
\text { et al. } 55\end{array}$} & \multirow[t]{4}{*}{2003} & \multirow[t]{4}{*}{ CRBSI \#\# } & \multirow[t]{4}{*}{$\begin{array}{c}\text { Retrospective } \\
\text { cohort }\end{array}$} & \multirow[t]{4}{*}{$\begin{array}{c}\text { 1997, } 30 \\
\text { months/USA }\end{array}$} & \multirow[t]{4}{*}{1,043} & \multirow[t]{4}{*}{$\begin{array}{l}0 \text { to } 18 \text { years } \\
\text { (median } 4.1 \\
\text { years) }\end{array}$} & \multirow[t]{4}{*}{$4.2(44)$} & & $\begin{array}{c}\text { By type of } \\
\text { catheter/1,000 } \\
\text { CVC - days }\end{array}$ \\
\hline & & & & & & & & & 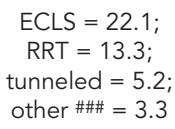 \\
\hline & & & & & & & & & $\begin{array}{l}\text { By number of } \\
\text { intravascular } \\
\text { accesses }\end{array}$ \\
\hline & & & & & & & & & $\begin{array}{c}\geq 3 \text { accesses } \\
=20.1 ; 2 \\
\text { accesses }= \\
12.1 ; 1 \text { access } \\
=4.0\end{array}$ \\
\hline $\begin{array}{l}\text { Almuneef } \\
\text { et al. } 56\end{array}$ & 2006 & CRBSI & $\begin{array}{c}\text { Prospective } \\
\text { cohort }\end{array}$ & $\begin{array}{c}\text { 2000, } 19 \\
\text { months/Saudi } \\
\text { Arabia }\end{array}$ & 501 & $\begin{array}{c}\text { Mean } 2.6 \pm 3.4 \\
\text { years }\end{array}$ & $9.98(50)$ & $9.18(46)$ & $\begin{array}{l}\text { 20.06/1,000 } \\
\text { CVC day }\end{array}$ \\
\hline $\begin{array}{l}\text { Elward } \\
\text { et al. } 57\end{array}$ & 2006 & $\mathrm{BSI}$ & $\begin{array}{c}\text { Prospective } \\
\text { cohort }\end{array}$ & $\begin{array}{c}\text { 1999, } 24 \\
\text { months/USA }\end{array}$ & 2,310 & $\begin{array}{c}\text { Includes }<28 \\
\text { days; } 0 \text { to } 18 \\
\text { years (median } \\
3.26 \text { years) }\end{array}$ & $5.36(124)$ & $3.76(87)$ & $\begin{array}{l}9.00 / 1,000 \\
\text { CVC day }\end{array}$ \\
\hline \multirow[t]{2}{*}{$\begin{array}{l}\text { Fayon } \\
\text { et al. } 58\end{array}$} & \multirow[t]{2}{*}{1997} & BNP & \multirow[t]{2}{*}{$\begin{array}{c}\text { Prospective } \\
\text { cohort }\end{array}$} & \multirow[t]{2}{*}{$\begin{array}{c}\text { 1991, } 13 \\
\text { months/Canada }\end{array}$} & \multirow[t]{2}{*}{960} & $\begin{array}{l}\text { Mean } \\
64.5 \pm 65.8 \\
\text { months }\end{array}$ & $1.2(12)$ & $1.2(12)$ & \multirow{2}{*}{$\begin{array}{c}\text { Mean BNP } \\
\text { and BNT }= \\
6.5 / 1,000 \text { days } \\
\text { of mechanical } \\
\text { ventilation }\end{array}$} \\
\hline & & BNT & & & & & $1.8(17)$ & $1.8(17)$ & \\
\hline $\begin{array}{l}\text { Elward } \\
\text { et al. } 59\end{array}$ & 2002 & VAP & $\begin{array}{c}\text { Prospective } \\
\text { cohort }\end{array}$ & $\begin{array}{c}\text { 1999, } 10 \\
\text { months/USA }\end{array}$ & 625 & $\begin{array}{l}\text { Mean } 5.5 \pm 5.9 \\
\text { years; median } \\
2.9 \text { years }\end{array}$ & $5.4(34)$ & $4.8(30)$ & $\begin{array}{c}11.6 / 1,000 \\
\text { ventilator-day }\end{array}$ \\
\hline
\end{tabular}

(continues)

Elward et al. 57 studied the use of central venous access as an extrinsic risk factor for bloodstream infection, whereas this variable was an inclusion criterion in the studies by Odetola et al. 55 and Almuneef et al. 56. The use of multiple catheters and parenteral nutrition were found to be significant risk factors for Almuneef et al. 56 . Only Elward et al. 57 assessed the number of packed red blood cell transfusions and they found that a high number was a significant risk factor. Hemodialysis was studied either separately 57 or associated to blood filtration and no significant association was found with BSI 55 . Odetola et al. 55 were the only authors to examine extracorporeal circulation and determined it to be a risk factor for BSI. 
Table 1 (continued)

\begin{tabular}{|c|c|c|c|c|c|c|c|c|c|}
\hline \multirow[t]{3}{*}{ Study } & \multirow[t]{3}{*}{ Year } & \multirow[t]{3}{*}{ Outcome } & \multicolumn{4}{|c|}{ Method } & \multicolumn{3}{|c|}{ HAl indicators } \\
\hline & & & \multirow[t]{2}{*}{ Design } & \multirow{2}{*}{$\begin{array}{l}\text { Year begun *, } \\
\text { duration and } \\
\text { setting }\end{array}$} & \multirow{2}{*}{$\begin{array}{l}\text { Number of } \\
\text { participants }\end{array}$} & \multirow[t]{2}{*}{ Age } & \multicolumn{2}{|c|}{ Accumulated incidence } & \multirow{2}{*}{$\begin{array}{c}\begin{array}{c}\text { Incidence } \\
\text { density \# }\end{array} \\
\text { HAl/1,000 } \\
\text { patients-day }\end{array}$} \\
\hline & & & & & & & $\begin{array}{l}\text { HAl rate ** } \\
\text { (n) }\end{array}$ & $\begin{array}{l}\text { PHAI rate } * \star \star \\
\text { (n) }\end{array}$ & \\
\hline $\begin{array}{l}\text { Almuneef } \\
\text { et al. } 60\end{array}$ & 2004 & VAP & $\begin{array}{c}\text { Prospective } \\
\text { cohort }\end{array}$ & $\begin{array}{c}\text { 2000, } 30 \\
\text { months/Saudi } \\
\text { Arabia }\end{array}$ & 361 & $\begin{array}{c}1 \text { month to } 12 \\
\text { years; median } 6 \\
\text { months }\end{array}$ & $10.24(37)$ & $10.24(37)$ & $\begin{array}{c}8.87 / 1,000 \\
\text { ventilator-day }\end{array}$ \\
\hline $\begin{array}{l}\text { Matlow } \\
\text { et al. } 49\end{array}$ & 2003 & UTI & $\begin{array}{l}\text { Retrospective } \\
\text { longitudinal }\end{array}$ & $\begin{array}{c}1997,20 \\
\text { months/Canada }\end{array}$ & 2,832 & Unreported & $0.95(27)$ & $0.95(25)$ & Unreported \\
\hline
\end{tabular}

CVC: central venous catheter; ECLS: extracorporeal life support; RRT: renal replacement therapy (dialysis or blood filtration); BSI: bloodstream infection; BNP: bacterial nosocomial pneumonia (corresponding to Nosocomial Infection Surveillance System 2004; PNEU: pneumonia, PNU2: with isolation of etiologic agent); BNT: bacterial nosocomial tracheitis (corresponding to Nosocomial Infection Surveillance System 2004, LRI-BRON: lower respiratory tract infection - bronchitis, tracheobronchitis, tracheitis without evidence of pneumonia); VAP: ventilator associated pneumonia (pneumonia associated to ventilation or ventilator); UTI: urinary tract infection.

* Year of start of study;

** HAl rate: number of episodes of $\mathrm{HAl} / 100$;

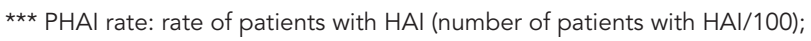

\# Incidence density: number of HAls/1,000 patients-days of exposure;

\#\# CRBSI: catheter-related bloodstream infection - as reported in Odetola et al. 55 and Almuneef et al. 56, corresponding to NNISS (National Nosocomial Infection Surveillance System) 2004, CABSI: catheter-associated bloodstream infection - in the presence of central venous catheter;

\#\#\# Others - umbilical venous catheter, PICC (peripherally-inserted central catheter).

The duration of arterial catheter use was a risk factor for BSI in the study by Elward et al. 57 whereas the duration of central catheter use remained in the final model in the Odetola et al. 55 study. Almuneef et al. 56 did not study these variables. Changing the catheter with a guidewire represented a nearly five-fold greater risk for BSI in the study by Almuneef et al. 56 but this was not assessed in the other two studies.

\section{Lower airway infection as outcome}

Three studies assessed risk factors for lower airway infection $58,59,60$. The incidence of healthcarerelated pneumonia was $1.2 \%, 5.4 \%$ and $10.2 \%$, respectively (Table 1 ). The latter two studies assessed ventilator associated pneumonia (VAP). Fayon et al. 58 also studied bacterial tracheitis, which had a cumulative incidence of $1.8 \%$, with an incidence density for grouped bacterial nosocomial tracheitis and bacterial pneumonia of 6.5 per 1,000 days on a ventilator. VAP rates were 11.6 and 8.87 per 1,000 days of ventilation in the studies by Elward et al. 59 and Almuneef et al. 60, respectively.

Factors related to underlying diseases were associated to bacterial tracheitis 58 (Table 4). With regard to bacterial pneumonia, the same study found an immunodeficiency status to be significant. Genetic syndrome was found to be a risk factor in the study by Elward et al. 59 for VAP. No intrinsic factors were significant in the study by Almuneef et al. 60.

Regarding extrinsic factors, Fayon et al. 58 found that the use of immunosuppressor drugs or neuromuscular blockers had a 4 -fold and 11-fold greater risk for healthcare-associated pneumonia, respectively. In the study by Elward et al. 59, transporting the patient out of the pediatric ICU was a risk factor for VAP. Almuneef et al. 60 found risks for VAP with prior antibiotic therapy, continuous enteral nutrition and bronchoscopy.

\section{Urinary tract infection as outcome}

In a retrospective study, Matlow et al. 49 identified 25 patients who developed 27 episodes of urinary tract infection among 2,832 admissions over 20 months (0.95 per 100 admissions). Heart surgery was identified as a significant adjusted risk factor (odds ratio, OR $=2.67 ; 95 \%$ confidence interval, 95\%CI: 1.13-6.32).

\section{Discussion}

Systematic reviews of observational studies have limitations that have been well described in the literature. However, such reviews are justified when there is interest in attempting to summarize association measurements between risk factors and illness outcomes that, for ethical rea- 
Table 2

Intrinsic and extrinsic risk factors for healthcare-associated infection (HAI) in pediatric Intensive Care Units (ICU) identified in the articles selected in the systematic review of observational studies published between 1987 and 2006.

\begin{tabular}{|c|c|c|c|c|c|c|}
\hline Study & Year & $\begin{array}{l}\text { Associated variables in } \\
\text { univariate analysis }\end{array}$ & Multivariate analysis & OR adjusted & $95 \% \mathrm{Cl}$ & $p$ value \\
\hline \multirow[t]{13}{*}{ Singh-Naz et al. 50} & 1996 & Intrinsic factors & Intrinsic factors & & & \\
\hline & & Age & PRISM * & 1.6 & $1.5-1.78$ & 0.0022 \\
\hline & & Weight & Post-operative & 2.6 & $1.215-6.0$ & 0.0224 \\
\hline & & $\begin{array}{l}\text { Immunity status ** (median of } \\
\text { sum of criteria) }\end{array}$ & & & & \\
\hline & & PRISM upon admission (mean) & & & & \\
\hline & & Extrinsic factors & Extrinsic factors & & & \\
\hline & & $\begin{array}{l}\text { Ratio of invasive } \\
\text { procedures }\end{array}$ & $\begin{array}{l}\text { Ratio of invasive } \\
\text { procedures } \star \star \star\end{array}$ & 2.36 & $1.6-3.5$ & 0.001 \\
\hline & & Use of $\mathrm{H}_{2}$ blocker & Antimicrobial therapy & 5.21 & $2.0-13.6$ & 0.0007 \\
\hline & & Parenteral nutrition & Parenteral nutrition & 22.1 & $7.1-68.8$ & 0.0001 \\
\hline & & $\begin{array}{c}\text { Length of stay in ICU } \\
\text { prior to HAI }\end{array}$ & $\begin{array}{l}\text { Length of stay in ICU } \\
\text { prior to HAI \# }\end{array}$ & 4.3 & $3.8-4.8$ & 0.0001 \\
\hline & & $\begin{array}{l}\text { Use of antimicrobial } \\
\text { agents (none, }<10 \text { days } \\
\text { and } \geq 10 \text { days) }\end{array}$ & $\begin{array}{c}\text { Post-operative and parenteral } \\
\text { nutrition \#\# }\end{array}$ & 0.3 & $0.1-0.9$ & 0.0261 \\
\hline & & & $\begin{array}{l}\text { PRISM and antimicrobial } \\
\text { therapy\#\#\# }\end{array}$ & 0.7 & $0.6-0.7$ & 0.011 \\
\hline & & & $\begin{array}{l}\text { Parenteral nutrition and } \\
\text { length of stay in ICU } \\
\text { prior to HAI } \S\end{array}$ & 0.2 & $0.2-0.3$ & 0.0001 \\
\hline \multirow[t]{8}{*}{ Gilio et al. 51} & 2000 & Intrinsic factors & Intrinsic factors & & & \\
\hline & & $\begin{array}{l}\text { Underlining condition } \\
\text { (sepsis and others, } \\
\text { excluding cardiovascular } \\
\text { surgery, multi-traumatism, } \\
\text { central nervous system } \\
\text { disease, respiratory } \\
\text { disease) }\end{array}$ & PRISM §§ & 1.047 & $0.891-1.230$ & 0.5744 \\
\hline & & & Post-operative & 1.030 & $0.508-2.089$ & 0.9920 \\
\hline & & & Extrinsic factors & & & \\
\hline & & & $\begin{array}{l}\text { Ratio of invasive } \\
\text { procedures } \S \S \S\end{array}$ & 1.609 & $1.104-2.345$ & 0.0132 \\
\hline & & & Antimicrobial therapy & 1.003 & $0.563-1.786$ & 0.9930 \\
\hline & & & Parenteral nutrition & 2.467 & $1.048-5.811$ & 0.0388 \\
\hline & & & $\begin{array}{l}\text { Length of stay in } \\
\text { ICU prior to HAI }\end{array}$ & 1.705 & $1.313-2.214$ & 0.0001 \\
\hline \multirow{6}{*}{$\begin{array}{l}\text { El-Nawawy } \\
\text { et al. } 52\end{array}$} & 2006 & Intrinsic factors & Intrinsic factors & & & \\
\hline & & PRISM III (mean \pm SD) & $\begin{array}{l}\text { Patient sent from } \\
\text { emergency ward }\end{array}$ & 0.269 & $0.178-0.406$ & \\
\hline & & $\begin{array}{l}\text { Underlining condition } \\
\text { (pneumonia, meningitis) }\end{array}$ & PRISM III & 1.073 & $1.041-1.105$ & \\
\hline & & Extrinsic factors & Extrinsic factors & & & \\
\hline & & Length of stay $\ddagger$ & Length of stay $>7$ days & 1.537 & $1.423-1.659$ & \\
\hline & & $\begin{array}{l}\text { Ward of origin } \\
\text { (emergency or other) }\end{array}$ & & & & \\
\hline
\end{tabular}

(continues) 
Table 2 (continued)

\begin{tabular}{|c|c|c|c|c|c|c|}
\hline Study & Year & $\begin{array}{l}\text { Associated variables in } \\
\text { univariate analysis }\end{array}$ & Multivariate analysis & OR adjusted & $95 \% \mathrm{Cl}$ & $p$ value \\
\hline \multirow[t]{10}{*}{ Figueiredo 54 㧊 } & 2002 & Intrinsic factors & Intrinsic factors & & & \\
\hline & & Age & Age & 1.27 & $1.06-1.54$ & 0.01 \\
\hline & & Post-operative period & $\begin{array}{c}\text { Nutritional state (weight z } \\
\text { score }<-2 \text { ) }\end{array}$ & 1.07 & $0.74-1.53$ & 0.71 \\
\hline & & Previous hospital infection & Previous hospital infection & 0.71 & $0.50-1.01$ & 0.05 \\
\hline & & & Post-operative & 2.08 & $1.31-3.29$ & 0.0000 \\
\hline & & Extrinsic factors & Extrinsic factors & & & \\
\hline & & Parenteral nutrition & Parenteral nutrition & 1.62 & $1.09-2.42$ & 0.02 \\
\hline & & Invasive procedures & Invasive procedure $\neq \neq \ddagger$ & 1.08 & $0.73-1.60$ & 0.63 \\
\hline & & $\begin{array}{l}\text { Duration of previous } \\
\text { antibiotic use - from admission } \\
\text { to hospital to first HAl in the } \\
\text { pediatric ICU }\end{array}$ & & & & \\
\hline & & $\begin{array}{c}\text { Previous antibiotics - number used } \\
\text { from admission to hospital } \\
\text { to first HAl in the } \\
\text { pediatric ICU }\end{array}$ & & & & \\
\hline
\end{tabular}

PRISM: Pediatric Risk of Mortality; SD: standart deviation.

* Score was estimated based on 14 physiological parameters during the first 24 hours since admission to the pediatric ICU;

** Assessed upon admission: no risk in immune function (absence of the criteria to follow), minor risk (total lymphocytes $<1,500 / \mathrm{mm}^{3}$, albumin $<2 \mathrm{~g} \%$

or corticoid use), moderate risk (neutrophil count $<500 / \mathrm{mm}^{3}$, AIDS diagnosis), major risk (no granulocyte, bone marrow transplant or anti-neoplasm

chemotherapy less than 6 months prior to admission). Maximum state of dysfunction as criterion for major risk;

$\star * \star$ Ratio of invasive procedures $=$ [central venous catheter - days] + [urinary catheter -days] + [mechanical ventilation - days]/Length of stay until day of HAl

diagnosis;

\# Singh-Naz et al. 73 - an increase of five days in length of stay was associated to a four-fold greater risk of developing HAI (OR = 4.3; $95 \% \mathrm{Cl}$ : 3.8-4,8); Gilio et

al. 51 categorized variable in five-day intervals;

\#\# Yes for both variables;

\#\#\# $>0$ but < 10 days of antimicrobial therapy and a four-point increase on the PRISM score;

$\S$ Yes for parenteral nutrition and a five-day increase in length of stay;

$\S \S$ Singh-Naz et al. 73 - an increase of four points of the PRISM score was associated to a 1.5-fold greater risk of developing $\mathrm{HAI}(\mathrm{OR}=1.6$; $95 \% \mathrm{Cl}$ : 1.5-1.7);

Gilio et al. 51 categorized variable in 4-point intervals;

$\S \S \S$ An increase of 1 unit;

₹ Mean duration of hospitalization;

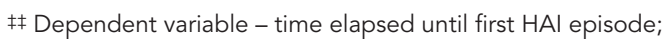

㧊 Categorized the number of invasive procedures (2 or less and more than 2).

sons, cannot be analyzed in clinical trials 111,112 . Although the importance of critically appraising articles is well recognized, there is no consensus on valid indicators for the quality of observational studies 113 . In the analysis of quality proposed by the Newcastle-Ottawa Scale, studies can obtain the maximum score even when presenting a number of sources of heterogeneity and bias.

Factors related to external validity should be pointed out: one of the pediatric ICUs only offered care to children and dependents of military personnel 56,60; and one of the Brazilian studies was carried out in a private hospital, the patients of which are not representative of the general community 51 .
Regarding the records of exposure and the detection of outcomes, there was a degree of homogeneity in the NNIS/CDC definitions and procedures for healthcare-associated infection. The opposite occurred for the categorization of exposure levels (intervals of PRISM scores; length of stay in the pediatric ICU or catheter use). Multidisciplinary pediatric ICUs were described as clinical-surgical pediatric ICUs, or the post-operative status was included as the underlying condition in the methodology. Age range was also heterogeneous, and it was unclear whether some studies included newborns and whether the upper age limit was 12 or 18 years. Occupational conditions, turnover and number 


\section{Table 3}

Intrinsic and extrinsic risk factors for bloodstream infection according to authors of the articles selected in the systematic review on "risk factors for healthcareassociated infection (HAl) in pediatric Intensive Care Units (ICU)".

\begin{tabular}{|c|c|c|c|c|c|c|c|}
\hline Study & Year & Outcome & $\begin{array}{l}\text { Associated variables in } \\
\text { the univariate analysis }\end{array}$ & $\begin{array}{l}\text { Multivariate } \\
\text { analysis }\end{array}$ & OR adjusted & $95 \% \mathrm{Cl}$ & $p$ value \\
\hline \multirow{13}{*}{$\begin{array}{l}\text { Elward et } \\
\text { al. } 57\end{array}$} & 2006 & $\mathrm{BSI}$ * & Intrinsic factors & Intrinsic factors & & & \\
\hline & & & $\begin{array}{c}\text { Age - median or }<30 \text { days, } 30 \text { days to } \\
1 \text { year, } 1 \text { to } 12 \text { years, }>12 \text { years }\end{array}$ & Genetic syndrome & 4.7 & $1.8-12$ & 0.001 \\
\hline & & & PRISM III - median & & & & \\
\hline & & & $\begin{array}{l}\text { Underlying condition: stunted growth, congenital } \\
\text { heart disease }\end{array}$ & & & & \\
\hline & & & Extrinsic factors & Extrinsic factors & & & \\
\hline & & & $\begin{array}{c}\text { Use of invasive procedures: central } \\
\text { venous catheter, multiple central accesses, } \\
\text { arterial catheter }\end{array}$ & $\begin{array}{l}\text { High number of } \\
\text { packed red blood } \\
\text { cell transfusions }\end{array}$ & 1.2 & $1.1-1.4$ & $<0.001$ \\
\hline & & & $\begin{array}{l}\text { Surgery or procedure: dialysis, } \\
\text { transplant and heart surgery }\end{array}$ & $\begin{array}{l}\text { Long duration of } \\
\text { arterial catheter } \\
\text { use - days }\end{array}$ & 5.7 & $3.4-9.8$ & $<0.001$ \\
\hline & & & $\begin{array}{l}\text { Transfusion: packed red blood cell } \\
\text { transfusions (mean) }\end{array}$ & & & & \\
\hline & & & $\begin{array}{l}\text { Locale where procedure was performed: } \\
\text { pediatric ICU }\end{array}$ & & & & \\
\hline & & & $\begin{array}{l}\text { Medications: prednisone, inotropic, } \\
\text { immunossupressor and } \mathrm{H}_{2} \text {. blocker }\end{array}$ & & & & \\
\hline & & & Parenteral nutrition & & & & \\
\hline & & & Transport outside of pediatric ICU & & & & \\
\hline & & & Transference from other unit & & & & \\
\hline \multirow{10}{*}{$\begin{array}{l}\text { Odetola } \\
\text { et al. } 55\end{array}$} & 2003 & CRBSI ** & Extrinsic factors & Intrinsic factors & & & \\
\hline & & & $\begin{array}{l}\text { Type of catheter (for renal replacement } \\
\text { therapy }{ }^{* * *} \text {, catheter for ECLS) }\end{array}$ & Age (in years) & 1.030 & $0.973-1.090$ & 0.304 \\
\hline & & & Number of accesses ( 2 and $\geq 3$ ) & & & & \\
\hline & & & & Extrinsic factors & & & \\
\hline & & & & $\begin{array}{l}\text { Tunneled } \\
\text { catheter }\end{array}$ & 1.061 & $0.397-2.835$ & 0.905 \\
\hline & & & & $\begin{array}{l}\text { Duration of } \\
\text { catheter use }\end{array}$ & 1.110 & $1.070-1.151$ & $<0.001$ \\
\hline & & & & $\begin{array}{l}\text { Parenteral } \\
\text { nutrition }\end{array}$ & 1.180 & $0.498-2.797$ & 0.707 \\
\hline & & & & $\begin{array}{l}\text { Mechanical } \\
\text { ventilation }\end{array}$ & 1.212 & $0.448-3.280$ & 0.705 \\
\hline & & & & $\begin{array}{l}\text { Catheter for } \\
\text { renal replacement } \\
\text { therapy }\end{array}$ & 2.330 & $0.914-5.940$ & 0.77 \\
\hline & & & & ECLS & 2.753 & $1.013-7.487$ & 0.047 \\
\hline
\end{tabular}

(continues) 


\begin{tabular}{|c|c|c|c|c|c|c|c|}
\hline Study & Year & Outcome & $\begin{array}{l}\text { Associated variables in } \\
\text { the univariate analysis }\end{array}$ & $\begin{array}{l}\text { Multivariate } \\
\text { analysis }\end{array}$ & OR adjusted & $95 \% \mathrm{Cl}$ & $p$ value \\
\hline \multirow{7}{*}{$\begin{array}{l}\text { Almuneef } \\
\text { et al. } 56\end{array}$} & 2006 & CRBSI \# & Intrinsic factors & Extrinsic factors & & & \\
\hline & & & Age (mean and older then 2 years) & $\begin{array}{l}\text { Parenteral } \\
\text { nutrition } \\
\text { through } \\
\text { catheter }\end{array}$ & 8.69 & $3.518-21.484$ & $<0.0001$ \\
\hline & & & Underlying condition (oncohematologic) & $\begin{array}{l}\text { Change of } \\
\text { catheter with } \\
\text { guidewire }\end{array}$ & 4.56 & $1.110-18.776$ & 0.04 \\
\hline & & & & $\begin{array}{c}\text { Multiple } \\
\text { central lines \#\# }\end{array}$ & 9.19 & $3.767-22.43$ & $<0.0001$ \\
\hline & & & Extrinsic factors & & & & \\
\hline & & & $\begin{array}{l}\text { Site of central venous catheter } \\
\text { (jugular and femoral) }\end{array}$ & & & & \\
\hline & & & $\begin{array}{l}\text { Locale where insertion of central venous } \\
\text { catheter was performed (surgery ward, } \\
\text { pediatric ICU or other) }\end{array}$ & & & & \\
\hline
\end{tabular}

BSI: bloodstream infection; PRISM: Paediatric Risk of Mortality; CRBSI: catheter-related bloodstream infection; ECLS: extracorporeal life support; CRBSI: catheter-related bloodstream infection.

* Elward et al. 59, primary infection that began after 48 or more hours of internment in the pediatric ICU, with the isolation of bacterium or fungus in the blood culture and that were not present in incubation prior to hospital admission. Coagulase-negative Staphylococcus was only considered as an etiological agent if blood culture was positive at least twice on separate occasions;

** Odetola et al. 55, primary bloodstream infection in patient with vascular access at least 48 hours prior to the establishment of the infection;

*** In the Odetola et al. 55 study refers to catheter with double or triple lumen for dialysis or blood filtration;

\# Almuneef et al. 56, bacteremia or fungemia in patient with intravascular catheter, with at least one positive blood culture obtained in peripheral vein with clinical manifestation of infection and no apparent source of bacteremia other than the catheter. Coagulase-negative Staphylococcus was only considered as an etiological agent if blood culture was positive at least twice on separate occasions;

\#\# In the Almuneef et al. 56 study refers to the use of other central venous catheters in comparison to a single central venous catheter.

of patients admitted in the pediatric ICUs also varied.

Structural factors, such as area and distribution of beds, availability of isolation beds, number of sinks or dispensers of products for hand hygiene and ratio of patients to healthcare workers, were not part of the analysis of the studies selected, nor were factors related to care processes and compliance to infection control protocols.

Among the four studies that analyzed healthcare-associated infection regardless of site of infection, only the Figueiredo study 54 found age to be a risk factor. The other authors did not discuss the association of age to healthcare-associated infection. The heterogeneity of the populations studied, especially in relation to age, hinders a comparison of the results. The currently accepted paradigm that the frequency of healthcareassociated infection in pediatrics is inversely proportional to age (more common among children under $12^{3,30}$ or 24 months 28,114 ) needs to be clarified, despite its biological plausibility: immunological immaturity could account for the higher incidence of healthcare-associated infection among younger patients 115 .

Many pediatric ICUs were clinical-surgical and catered for a large variety of conditions, making it difficult to establish associations between risk and underlying disease or severity of the condition. The post-operative period per se was a risk factor for healthcare-associated infection 50,54. Severity, as assessed by the PRISM score, was significant in four studies, but differences in the scores employed (PRISM has 14 clinical and laboratory parameters, whereas PRISM III has 17) and in the manner of categorizing the variable did not allow for summarizing how the measurement is associated with healthcare-associated infection.

Among extrinsic factors, the length of stay in the pediatric ICU was found to be the only risk factor for healthcare-associated infection in three studies $50,51,52$. Pediatric ICU stay reflects the severity of the condition, requiring greater care, but also expresses a measure of time in which the patient is potentially exposed to diverse sources of infection. Thus, NNIS recommendations focus 
Table 4

Intrinsic and extrinsic risk factors for healthcare-related pneumonia and traqueitis and pneumonia associated to the respirator according to authors of the articles selected in the systematic review on "risk factors for healthcare-associated infection in pediatric Intensive Care Units (ICU)".

\begin{tabular}{|c|c|c|c|c|c|c|c|}
\hline Study & Year & Outcome & $\begin{array}{l}\text { Variables associated in } \\
\text { the univariate analysis }\end{array}$ & $\begin{array}{l}\text { Multivariate } \\
\text { analysis }\end{array}$ & OR adjusted & $95 \% \mathrm{Cl}$ & $p$ value \\
\hline \multirow{17}{*}{$\begin{array}{l}\text { Fayon et } \\
\text { al. } 58\end{array}$} & 1997 & $\mathrm{BNP}$ * & Intrinsic factors & Intrinsic factors & & & \\
\hline & & & $\begin{array}{l}\text { PRISM upon admission and worse } \\
\text { score upon evolution }\end{array}$ & Age $\leq$ two months & 6.1 & $4.0-8.2$ & 0.02 \\
\hline & & & $\begin{array}{c}\text { Underlying condition: multiple organ failures } \\
\text { or failure of one of the systems, such as } \\
\text { respiratory, cardiovascular, neurological, } \\
\text { hematological or renal failure; SARA, } \\
\text { immunodeficiency }\end{array}$ & Male gender & 1.7 & - & NS \\
\hline & & & & Immunodeficiency ** & 6.9 & 4.1-9.7 & 0.06 \\
\hline & & & Extrinsic factors & Extrinsic factors & & & \\
\hline & & & Mechanical ventilation & Neuromuscular block & 11.4 & $9.5-13.3$ & 0.02 \\
\hline & & & Enteral nutrition & $\begin{array}{l}\text { Immunossupressor } \\
\text { drugs }\end{array}$ & 4.8 & $2.7-6.9$ & 0.04 \\
\hline & & & $\begin{array}{l}\text { Drugs: immunossupressor, blocker } \\
\text { neuromuscular, ranitidine, sucralfate }\end{array}$ & & & & \\
\hline & & $\mathrm{BNT}$ * & Intrinsic factors & Intrinsic factors & & & \\
\hline & & & Gender & Age $\leq 28$ months & 3.1 & $1.1-5.1$ & 0.10 \\
\hline & & & Age - mean in months & Male gender & 2.4 & $0-4.8$ & NS \\
\hline & & & $\begin{array}{l}\text { PRISM upon admission and worse } \\
\text { score upon evolution }\end{array}$ & Respiratory failure & 8.4 & $6.5-10.3$ & 0.001 \\
\hline & & & Worse score on Glasgow Coma Scale & Head trauma & 12.5 & $9.8-15.2$ & 0.01 \\
\hline & & & $\begin{array}{c}\text { Underlying condition: organ failure - multiple } \\
\text { organ failures or respiratory failure - cranial } \\
\text { trauma }\end{array}$ & & & & \\
\hline & & & Extrinsic factors & & & & \\
\hline & & & $\begin{array}{l}\text { Procedures: intubation, } \\
\text { mechanical ventilation }\end{array}$ & & & & \\
\hline & & & Neuromuscular blocker & & & & \\
\hline \multirow{9}{*}{$\begin{array}{l}\text { Elward et } \\
\text { al. } 59\end{array}$} & 2002 & VAP \# & Intrinsic factors & Intrinsic factors & & & \\
\hline & & & PRISM upon admission $\geq 10$ & Genetic syndrome & 2.37 & $1.03-5.46$ & 0.043 \\
\hline & & & $\begin{array}{l}\text { Underlying condition: burns, genetic } \\
\text { syndrome, bloodstream infection }\end{array}$ & & & & \\
\hline & & & Extrinsic factors & Extrinsic factors & & & \\
\hline & & & $\begin{array}{l}\text { Procedures: reintubation, tracheostomy, } \\
\text { bronchoscopy, toracocentesis, central } \\
\text { venous catheter. }\end{array}$ & $\begin{array}{l}\text { Transport out of } \\
\text { pediatric ICU \#\# }\end{array}$ & 8.90 & $3.82-20.7$ & 0.0001 \\
\hline & & & $\begin{array}{l}\text { Drugs: Histamine-2 receptor } \\
\text { blocker, steroids }\end{array}$ & Reintubation \#\#\# & 2.71 & $1.18-6.21$ & 0.011 \\
\hline & & & Parenteral nutrition & $\begin{array}{l}\text { Transfusion prior to } \\
\text { infection }\end{array}$ & - & - & 0.884 \\
\hline & & & Transfusion of blood products & & & & \\
\hline & & & Transport outside of pediatric ICU & & & & \\
\hline
\end{tabular}

(continues) 
Table 4 (continued)

\begin{tabular}{|c|c|c|c|c|c|c|c|}
\hline Study & Year & Outcome & $\begin{array}{l}\text { Variables associated in } \\
\text { the univariate analysis }\end{array}$ & $\begin{array}{l}\text { Multivariate } \\
\text { analysis }\end{array}$ & OR adjusted & $95 \% \mathrm{Cl}$ & $p$ value \\
\hline \multirow{6}{*}{$\begin{array}{l}\text { Almuneef } \\
\text { et al. } 60\end{array}$} & 2004 & VAP $\S$ & Extrinsic factors & Extrinsic factors & & & \\
\hline & & & $\begin{array}{l}\text { Accidental extubation } \\
\text { or reintubation }\end{array}$ & $\begin{array}{l}\text { Reintubation or } \\
\text { accidental } \\
\text { extubation \#\# }\end{array}$ & 1.62 & $0.776-3.370$ & 0.1992 \\
\hline & & & Bronchoscopy & $\begin{array}{l}\text { Witnessed } \\
\text { aspiration }\end{array}$ & 2.17 & $0.588-8.010$ & 0.2446 \\
\hline & & & Continuous enteral nutrition & $\begin{array}{c}\text { Previous antibiotic } \\
\text { therapy }\end{array}$ & 2.45 & $1.112-5.405$ & 0.0262 \\
\hline & & & Previous antibiotic therapy & $\begin{array}{c}\text { Continuous enteral } \\
\text { nutrition }\end{array}$ & 2.29 & $1.093-4.798$ & 0.0042 \\
\hline & & & Witnessed aspiration & Bronchoscopy & 5.04 & $1.665-15.266$ & 0.0008 \\
\hline
\end{tabular}

BNP: bacterial nosocomial pneumonia; BNT: bacterial nosocomial tracheitis; PRISM: Paediatric Risk of Mortality; VAP: ventilator associated pneumonia.

* Fayon et al. 58 consensus among 3 "blinded" experts ( 2 intensivists and 1 bacteriologist), using Centers for Disease Control and Prevention criteria and analyzing evocative signs and symptoms (purulent secretions, fever, new consolidation on thorax radiography, etc.) In intubated patients, tracheal aspirations were collected through a tracheal probe or tracheostomy and immediately sent to the laboratory for gram determination and culture. The patient was considered colonized in the presence of normal flora of the upper tract or if more than two different bacteria were identified in small quantities in the secretions without any formation of pus ( $<25$ polymorphonuclears per field);

** Congenital (ex: adenosine desaminase deficiency) or acquired (ex: AIDS);

$\star \star \star$ Barbiturates in high dose ( $\geq 30 \mathrm{mg} / \mathrm{kg} /$ day), cyclosporine, azathioprine and corticosteroids;

\# Elward et al. 59 - patient on mechanical ventilation for at least 48 hours, presenting new infiltration on the thorax radiography 48 hours or more after initiating mechanical ventilation. Additionally, the patient must have 2 or more of the following: fever $>38^{\circ} \mathrm{C}$, leukocytosis (> 12,000) and the appearance of purulent sputum (> 25 leukocytes per field in the GRAM). Associated organisms were designated as those recovered from the tracheal aspiration or bronchoalveolar lavage in patients with respirator-associated pneumonia;

\#\# Moving the patient out of the pediatric ICU for surgery or imaging exams;

\#\#\# Reported in the study by Almuneef et al. 83; the study by Elward et al. 59 only mentions reintubation;

$\S$ Almuneef et al. 83 - patient on mechanical ventilation for at least 48 hours, presenting new or progressive infiltrate, consolidation, cavitation or pleural effusion on the thorax radiography. Additionally, the patient must have: appearance of purulent sputum or change in the appearance of phlegm; microorganism isolated in the blood culture not related to other source of infection; isolation of pathogens of specimen obtained from tracheal aspiration, bronchoalveolar lavage or protected pulmonary brushing or biopsy; or histopathologic with evidence of pneumonia in pulmonary biopsy.

primarily on time reduction in the use of invasive procedures. The diversity of the categorization of the variable "length of stay in the pediatric ICU" renders the summarization of the association measure unfeasible. It was also not possible to summarize the association measures between healthcare-associated infection and the invasive procedure ratio 50,51 or the use of parenteral nutrition $50,51,54$ due to the unavailability of tabled data in the articles.

One of the characteristics of healthcare-associated infection in the pediatric ICU is that BSI is the most frequent type of infection ${ }^{6}$. As in adults, BSI in the pediatric ICU is nearly always associated with the use of a central venous catheter $27,30,61$. Except in specialized ICUs for burn victims or newborns weighing less than $1,000 \mathrm{~g}$, the NHSN (which replaced the NNIS) reports that it is in the clinical-surgical pediatric ICU that BSI associated to a central venous catheter which has the highest incidences 8 .
Regarding BSI-LCBI, the incidence density observed in the present review was as high or higher than NHSN references for clinical-surgical pediatric ICU 56,57. This indicator currently includes only BSI associated to a central venous catheter with bacteriological confirmation, whereas, previously, clinical sepsis was included8. Without reporting an overall rate, Odetola et al. 55 analyzed an increasing incidence density according to the number of intravascular accesses and characteristics of the catheter type or use, finding rates that ranged from 4.0 to 22.1 / 1,000 catheterdays.

Regarding risk factors for BSI in the pediatric ICU, the use of an arterial or venous catheter, devices with multiple lumens, changing the catheter with a guidewire, central vein parenteral nutrition, extracorporeal circulation and packed red cell transfusions are risk factors that are potentially modifiable through educative measures. In turn, a genetic syndrome may be a marker of 
immune defects that impede the defense of the host against microorganisms. However, it should be stressed that in the three studies that analyzed BSI in the pediatric ICU, no common risk factors were found 55,57 .

In the prevention of infection associated to a central venous catheter, the "package" of interventions proposed in a campaign by American hospitals to save 100,000 lives addressed five components: hand hygiene, maximal sterile barrier, skin antisepsis with chlorhexidine, the choice of the subclavian vein as the preferred insertion site for non-tunneled catheters and daily checks with immediate removal if central access is no longer necessary 116. Based on these recommendations, Lee \& Johston 117 published a systematic review seeking the best evidence for handling central venous catheters and the prevention of bloodstream infections associated to catheters in the pediatric population and concluded that the quality and diversity of the articles in relation to the outcome did not allow the establishment of clear guidelines, such as those existing for adults.

The present systematic review, together with that by Lee \& Johnston 117 and other narrative reviews, stress the fact that most of the current knowledge on bloodstream infection related to central venous catheters has principally emerged from data collected in adult ICUs 118,119. The interventions currently recommended regarding the use of central venous catheters are the same from the 100,000 lives campaign 120 . Although the pediatric ICUs have high rates of BSI associated to central venous catheters, the mean percentage of use (approximately 50\%) of this procedure is among the lowest when considering the different types of ICU 8,121 . Thus, recommendations regarding the identification of factors other than the frequency of central access per se seem to be particularly necessary.

Pneumonia is among the three main types of infection in the pediatric ICU and, as in adults, is more frequent among patients on mechanical ventilation $4,27,30,31,61$. The diagnosis of VAP, however, is challenging and may explain the differences in the diverse studies concerning the occurrence of this event as well as possible risk factors. Taking into account the difficulty in diagnosing nosocomial pneumonia or tracheitis, Fayon et al. 58 used a consensus between three researchers, two intensivists and one microbiologist. Agreement was good for pneumonia and weak for tracheitis. Recent criteria aimed at improving the specificity of this diagnosis were stipulated by the NNIS for both adults and children 122 , but need to be validated with regard to pediatric patients.
The heterogeneity of the three studies on risk factors for lower airway infection impeded the summarization of the measures found 58,59,60. The outcomes were different: tracheitis and pneumonia, in which endotracheal intubation was one of the risk factors 58; and ventilator-associated pneumonia, in which being on a ventilator was a criterion for inclusion 59,60. The studies analyzing VAP found different independent risk factors and no risk factors that were common to both studies 59,60 .

In a systematic review of intervention studies based on risk factors for VAP, the authors graded the prevention recommendations according to the quality of the studies, but none was based on a pediatric population 123 . Recommendations were extrapolated for children and adolescents: elevation of the head between 30 and 45 degrees, daily verification of sedation and the possibility of extubation, prophylaxis for peptic ulcers and deep venous thrombosis 116 .

Urinary tract infection is the main cause of healthcare-associated infection in adults, but is scarcely studied in the pediatric ICU, despite being considered the third most frequent type of infection. Only two of the 84 studies in the present review discussed risk factors for urinary tract infection and one of these failed to present multivariate analysis 62 . The study by Matlow et al. 49 presents several methodological difficulties for being a retrospective study, including the impossibility of calculating the incidence density in relation to catheter use in the exposed and non-exposed populations, which is the main risk factor reported in the literature. Despite the relatively lesser use of urinary catheters in children in the pediatric ICU (mean use ratio of approximately 0.30 ), the rate of infection remains high, with a median value of 2.8 per 1,000 urinary cathetersdays 8 , indicating the presence of risk factors likely associated to urinary catheter use. EPIC 2 (Evidence based Practice in Infection Control) recommendations for the prevention of infection associated to the use of short-term urinary catheters only applied to adults and children over the age of one, and a number of reviews cited were of studies on adult patients 24 .

Children have anatomical and functional peculiarities, different underlying conditions and are submitted to different surgical procedures than adults. This justifies the conducting of specific studies on pediatric patients 59. An important step toward determining specificities and improving the comparison of healthcare-associated infection surveillance in the pediatric ICU was the definition of different types of pediatric ICU considered in the new system adopted by the NHSN 8,124. A number of reviews have sought 
to establish a consensus among the different medical societies and governmental surveillance agencies for the standardization of definitions regarding the types of infection - sepsis, pneumonia and urinary tract infection 125,126,127.

The present systematic review demonstrates the scarcity of studies on risk factors for healthcare-associated infection in children hospitalized in pediatric intensive care units. The following were risk factors for a first episode of healthcare-associated infection: post-operative period, greater severity upon admission based on the PRISM or PRISM III, invasive procedures, the use of antimicrobial agents, parenteral nutrition, remaining more days or more than seven days in the pediatric ICU. However, being sent from the emergency ward is a protective factor. Risk factors identified for BSI-LCBI were: age, genetic syndrome, use of packed red cells, long duration of catheter use, parenteral nutrition through a catheter, change of catheter with a guidewire, multiple central lines and extracorporeal circulation. The development of bacterial pneumonia were associated to the following risk factors: young age, immunodeficiency, neuromuscular blocker and immunosupressor drugs; for tracheitis: age $\leq 28$ months, respiratory failure, head trauma; for VAP: genetic syndrome, transport outside of the pediatric ICU, reintubation, bronchoscopy and continuous enteral nutrition.

Risk factors for healthcare-associated infection in PICUs stem from the dynamics of healthcare in child or adolescent units and are specific to these populations.

This systematic review demonstrated that the production of evidence on risk factors in paediatric ICUs has not kept up the same pace of that on adult ICUs. There are few studies on the subject with adequate design and statistical analysis. Furthermore, the methodological diversity of the studies requires a systematic analysis of the scientific evidence produced on this topic. Efforts should be made to obtain data on risk factors utilizing standardized prospective protocols to measure these different factors. Recommendations drafted from evidence produced in pediatric ICUs would be more adequate for contributing to control strategies of these adverse healthcare events, thereby ensuring the safety of children who require intensive care.

\section{Resumo}

Realizou-se revisão sistemática de estudos observacionais sobre fatores de risco para infecção relacionada aos cuidados de saúde em Unidades de Terapia Intensiva (UTI) pediátrica. Foram incluídos estudos em inglês, francês, espanhol ou português indexados no MEDLINE, LILACS, Cochrane Library, BDENF, CAPES, entre 1987 e 2006. As palavras-chave foram "Infecção Hospitalar" e "Unidades de Terapia Intensiva Pediátricas", com diferentes formas de escrever. Onze artigos foram selecionados a partir de 419 resumos encontrados: quatro tinham como desfecho infecção em qualquer topografia; três eram sobre infecções de vias aéreas inferiores; três estudaram infecção da corrente sanguínea confirmada laboratorialmente e um analisou infecção do trato urinário. A produção de evidências na UTI pediátrica não vem acompanhando o ritmo dos estudos em adultos - existem poucos estudos com desenhos e análise estatística adequados. A diversidade metodológica não permitiu a realização de medição sumarizada dos fatores de risco.

Infecção Hospitalar; Unidades de Terapia Intensiva Pediátrica; Assistência à Saúde

\section{Contributors}

M. J. G. Mello accessed the databases; read the selected summaries and complete articles; carried out the data extraction; analyzed the quality of the chosen articles and wrote the article. M. F. P. M. Albuquerque read the selected summaries and complete articles; participated in the data extraction; and helped in the write up. H. R. Lacerda participated in the design of the protocol for data extraction; analyzed the results of the selected articles; and helped in the write up. W. V. Souza analyzed the quality of the chosen articles, according to the "Newcastle-Ottawa Scale" protocol; analyzed the heterogeneity of the results and the possibility of summarizing the measures for associations found in the studies. J. B. Correia participated in the preparation of the protocol for data extraction and the article write up. M. C. A. Britto participated in the preparation of the protocol for data extraction and the article write up. 


\section{References}

1. Burke JP. Infection control: a problem for patient safety. N Engl J Med 2003; 348:651-6.

2. Graves N. Economics and preventing hospital-acquired infection. Emerg Infect Dis 2004; 10:561-6.

3. Jarvis WR. Epidemiology of nosocomial infections in paediatric patients. Pediatr Infect Dis J 1987; 6:344-51.

4. Stover BH, Shulman ST, Bratcher DF, Brady MT, Levine GL, Jarvis WR. Paediatric Prevention Network. Nosocomial infection rates in US children's hospitals' neonatal and paediatric intensive care units. Am J Infect Control 2001; 29:152-7.

5. Garner JS, Jarvis WR, Emori TG, Horan TC, Hughes JM. CDC definitions for nosocomial infections. Am J Infect Control 1988; 16:128-40.

6. Emori TG, Culver DH, Horan TC, Jarvis WR, White JW, Olson DR, et al. National nosocomial infections surveillance system (NNIS): description of surveillance methods. Am J Infect Control 1991; 19:19-35.

7. Horan TC, Emori TG. Definitions of key terms used in the NNIS System. Am J Infect Control 1997; 25:112-6.

8. Edwards JR, Peterson KD, Andrus ML, Tolson JS, Goulding JS, Dudeck MA, et al. National Healthcare Safety Network (NHSN) report, data summary for 2006, issued June 2007. Am J Infect Control 2007; 35:290-301.

9. Pollack MM, Ruttimann UE, Getson PR. Paediatric risk of mortality (PRISM) score. Crit Care Med 1988; 16:1110-6.

10. Pollack MM, Patel KM, Ruttimann UE. PRISM III: an updated paediatric risk of mortality score. Crit Care Med 1996; 24:743-52.

11. Shann F, Pearson G, Slater A, Wilkinson K. Paediatric index of mortality (PIM): a mortality prediction model for children in intensive care. Intensive Care Med 1997; 23:201-7.

12. Slater A, Shann F, Pearson G. Paediatric Index of Mortality (PIM) study group. PIM2: a revised version of the Paediatric Index of Mortality. Intensive Care Med 2003; 29:278-85.

13. Pearson GA, Stickley J, Shann F. Calibration of the paediatric index of mortality in UK paediatric intensive care units. Arch Dis Child 2001; 84:125-8.

14. Bueno-Cavanillas A, Rodríguez-Contreras $\mathrm{R}$, López-Luque A, Delgado-Rodríguez M, GálvesVargas R. Usefulness of severity indices in intensive care medicine as a predictor of nosocomial infection risk. Intensive Care Med 1991; 17:336-9.

15. Keita-Perse O, Gaynes RP. Severity of illness scoring systems to adjust nosocomial infection rates: a review and commentary. Am J Infect Control 1996; 24:429-34.

16. Couto RC, Pedrosa TMG. Epidemiologia hospitalar In: Couto RC, Pedrosa TMG, Nogueira JM, organizadores. Infecção hospitalar e outras complicações não-infecciosas da doença: epidemiologia, controle e tratamento. Rio de Janeiro: Editora Medsi; 2003. p. 93-155.

17. Wong ES, Hooton TM. Guideline for prevention of catheter-associated Urinary Tract Infections. Atlanta: Centers for Disease Control and Prevention; 1981. http://www.cdc.gov/ncidod/dhqp/gl catheter_assoc.html (accessed on 10/Dec/2005).
18. Mangram AJ, Horan TC, Pearson ML, Silver LC, Jarvis WR. Guideline for prevention of surgical site infection, 1999. Hospital Infection Control Practices Advisory Committee. Infect Control Hosp Epidemiol 1999; 20:250-78.

19. Pratt RJ, Pellowe C, Loveday HP, Robinson N, Smith GW, Barrett S, et al. The epic project: developing national evidence-based guidelines for preventing healthcare associated infections. Phase I: guidelines for preventing hospital-acquired infections. Department of Health (England). J Hosp Infect 2001; 47 Suppl:S3-82.

20. O'Grady NP, Alexander M, Dellinger EP, Gerberding JL, Heard SO, Maki DG, et al. Guidelines for the prevention of intravascular catheter-related infections. MMWR Recomm Rep 2002; 51(RR-10):1-29.

21. Boyce JM, Pittet D; Healthcare Infection Control Practices Advisory Committee; HICPAC/SHEA/ APIC/IDSA Hand Hygiene Task Force. Guideline for Hand Hygiene in Health-Care Settings. Recommendations of the Healthcare Infection Control Practices Advisory Committee and the HICPAC/ SHEA/APIC/IDSA Hand Hygiene Task Force. Society for Healthcare Epidemiology of America/Association for Professionals in Infection Control/ Infectious Diseases Society of America. MMWR Recomm Rep 2002; 51(RR-16):1-45.

22. Tablan OC, Anderson LJ, Besser R, Bridges C, Hajjeh R; Centers for Disease Control and Prevention, et al. Guidelines for preventing health-care-associated pneumonia, 2003: recommendations of CDC and the Healthcare Infection Control Practices Advisory Committee. MMWR Recomm Rep 2004; 53(RR-3):1-36.

23. American Thoracic Society/Infectious Diseases Society of America. Guidelines for the management of adults with hospital-acquired, ventilator-associated, and healthcare-associated pneumonia. Am J Respir Crit Care Med 2005; 171:388-416.

24. Pratt RJ, Pellowe CM, Wilson JA, Loveday HP, Harper PJ, Jones SRLJ, et al. National evidence-based guidelines for preventing healthcare-associated infections in NHS hospitals in England. J Hosp Infect 2007; 65 Suppl 1:S1-64.

25. Harris JA. Paediatric nosocomial infections: children are not little adults. Infect Control Hosp Epidemiol 1997; 18:739-42.

26. Stroup DF, Berlin JA, Morton SC, Olkin I, Williamson GD, Rennie D, et al. Meta-analysis of observational studies in epidemiology: a proposal for reporting. JAMA 2000; 283:2008-12.

27. Richards MJ, Edwards JR, Culver DH, Gaynes RP. Nosocomial infections in paediatric intensive care units in the United States. National Nosocomial Infections Surveillance System. Pediatrics 1999; 103:e39.

28. Milliken J. Nosocomial infections in a paediatric intensive care unit. Crit Care Med 1988; 16: 233-7.

29. Azahares Romero LE, Pérez Monrás MF, Rodríguez MA, Rodríguez GDP, Zuazo Silva JL. Infección nosocomial en la unidad de cuidados intensivos: Hospital Pediátrico Docente "Centro Habana", 1985. Rev Cubana Hig Epidemiol 1989; 27:177-88. 
30. Grohskopf LA, Sinkowitz-Cochran RL, Garrett DO, Sohn AH, Levine GL, Siegel JD, et al. Paediatric Prevention Network. A national point-prevalence survey of paediatric intensive care unit-acquired infections in the United States. J Pediatr 2002; 140:432-8.

31. Raymond J, Aujard Y. Nosocomial infections in paediatric patients: a European, multicenter prospective study. European Study Group. Infect Control Hosp Epidemiol 2000; 21:260-3.

32. Nourdine K, Combes P, Carton M-J, Beuret P, Cannamela A, Ducreux JC. Does noninvasive ventilation reduce the ICU nosocomial infection risk? A prospective clinical survey. Intensive Care Med 1999; 25:567-73.

33. Bowen-Jones J, Wesley A, van den Ende J. Nosocomial colonisation and infection in a paediatric respiratory intensive care unit. S Afr Med J 1992; 82:309-13

34. Albers MJ, Mouton JW, Tibboel D. Colonization and infection by Serratia species in a paediatric surgical intensive care unit. J Hosp Infect 2001; 48:7-12.

35. Arantes A, Carvalho ES, Medeiros EA, Farhat CK, Mantese OC. Paediatric risk of mortality and hospital infection. Infect Control Hosp Epidemiol 2004; 25:783-5.

36. San Miguel LG, Cobo J, Otheo E, Martos I, Muriel A, Fortún J, et al. Candidemia in paediatric patients with congenital heart disease. Diagn Microbiol Infect Dis 2006; 55:203-7.

37. Chiu NC, Chung YF, Huang FY. Paediatric nosocomial fungal infections. Southeast Asian J Trop Med Public Health 1997; 28:191-5.

38. Cavalcante SS, Mota E, Silva LR, Teixeira LF, Cavalcante LB. Risk factors for developing nosocomial infections among paediatric patients. Pediatr Infect Dis J 2006; 25:438-45.

39. Asensio A, Oliver A, González-Diego P, Baquero F, Pérez-Díaz JC, Ros P, et al. Outbreak of a multiresistant Klebsiella pneumoniae strain in an intensive care unit: antibiotic use as risk factor for colonization and infection. Clin Infect Dis 2000; 30:55-60.

40. Pasqualotto AC, Sukiennik TC, Severo LC, Amorim CS, Colombo AL. An outbreak of Pichia anomala fungemia in a Brazilian paediatric intensive care unit. Infect Control Hosp Epidemiol 2005; 26:553-8.

41. Yogaraj JS, Elward AM, Fraser VJ. Rate, risk factors, and outcomes of nosocomial primary bloodstream infection in paediatric intensive care unit patients. Pediatrics 2002; 110:481-5.

42. Singh-Naz N, Sprague BM, Patel KM, Pollack MM. Risk assessment and standardized nosocomial infection rate in critically ill children. Crit Care Med 2000; 28:2069-75.

43. Pollock EM, Ford-Jones EL, Rebeyka I, Mindorff CM, Bohn DJ, Edmonds JF, et al. Early nosocomial infections in paediatric cardiovascular surgery patients. Crit Care Med 1990; 18:378-84.

44. Mehta PA, Cunningham CK, Colella CB, Alferis G, Weiner LB. Risk factors for sternal wound and other infections in paediatric cardiac surgery patients. Pediatr Infect Dis J 2000; 19:1000-4.
45. Levy I, Ovadia B, Erez E, Rinat S, Ashkenazi S, Birk E, et al. Nosocomial infections after cardiac surgery in infants and children: incidence and risk factors. J Hosp Infect 2003; 53:111-6.

46. Tan L, Sun X, Zhu X, Zhang Z, Li J, Shu Q. Epidemiology of nosocomial pneumonia in infants after cardiac surgery. Chest 2004; 125:410-7.

47. Citak A, Karaböcüoglu M, Uçsel R, Ugur-Baysal $\mathrm{S}$, Uzel N. Bacterial nosocomial infections in mechanically ventilated children. Turk J Pediatr 2000; 42:39-42.

48. Tullu MS, Deshmukh CT, Baveja SM. Bacterial nosocomial pneumonia in Paediatric Intensive Care Unit. J Postgrad Med 2000; 46:18-22.

49. Matlow AG, Wray RD, Cox PN. Nosocomial urinary tract infections in children in a paediatric intensive care unit: a follow-up after 10 years. Pediatr Crit Care Med 2003; 4:74-7.

50. Singh-Naz N, Sprague BM, Patel KM, Pollack MM. Risk factors for nosocomial infection in critically ill children: a prospective cohort study. Crit Care Med 1996; 24:875-8.

51. Gilio AE, Stape A, Pereira CR, Cardoso MF, Silva CV Troster EJ. Risk factors for nosocomial infections in a critically ill paediatric population: a 25 -month prospective cohort study. Infect Control Hosp Epidemiol 2000; 21:340-2.

52. El-Nawawy AA, Abd El-Fattah MM, Metwally HA, Barakat SS, Hassan IA. One year study of bacterial and fungal nosocomial infections among patients in paediatric intensive care unit (PICU) in Alexandria. J Trop Pediatr 2006; 52:185-91.

53. Arantes A. Avaliação das infecções hospitalares em unidade de terapia intensiva pediátrica [Dissertação de Mestrado]. São Paulo: Universidade Federal de São Paulo; 2001.

54. Figueiredo MR. Infecção hospitalar em crianças admitidas em Unidade de Tratamento Intensivo: estudo de seguimento no Instituto Fernandes Figueira, janeiro/1997 - setembro/2000 [Dissertação de Mestrado]. Rio de Janeiro: Universidade do Estado do Rio de Janeiro; 2002.

55. Odetola FO, Moler FW, Dechert RE, van der Elzen K, Chenoweth C. Nosocomial catheter-related bloodstream infections in a paediatric intensive care unit: risk and rates associated with various intravascular technologies. Pediatr Crit Care Med 2003; 4:432-6.

56. Almuneef MA, Memish ZA, Balkhy HH, Hijazi O, Cunningham G, Francis C. Rate, risk factors and outcomes of catheter related bloodstream infection in a paediatric intensive care unit in Saudi Arabia. J Hosp Infect 2006; 62:207-13.

57. Elward AM, Fraser VJ. Risk factors for nosocomial primary bloodstream infection in paediatric intensive care unit patients: a 2-year prospective cohort study. Infect Control Hosp Epidemiol 2006; 27: 553-60.

58. Fayon MJ, Tucci M, Lacroix J, Farrell CA, Gauthier M, Lafleur L, et al. Nosocomial pneumonia and tracheitis in a paediatric intensive care unit: a prospective study. Am J Respir Crit Care Med 1997; 155:162-9. 
59. Elward AM, Warren DK, Fraser VJ. Ventilator-associated pneumonia in paediatric Intensive Care Unit patients: risk factors and outcomes. Pediatrics 2002; 109:758-64.

60. Almuneef M, Memish ZA, Balkhy HH, Alalem H, Abutaleb A. Ventilator-associated pneumonia in a paediatric intensive care unit in Saudi Arabia: a 30-month prospective surveillance. Infect Control Hosp Epidemiol 2004; 25:753-8.

61. Jarvis WR, Edwards JR, Culver DH, Hughes JM, Horan T, Emori TG, et al. Nosocomial infection rates in adult and paediatric intensive care units in the United States. National Nosocomial Infections Surveillance System. Am J Med 1991; 91(3B): 185S-91S.

62. Tullu MS, Deshmukh CT, Baveja SM. Urinary catheter related nosocomial infections in paediatric intensive care unit. J Postgrad Med 1998; 44:35-9.

63. Pérez Monrás M, Azahares Romero L, Zuazo Silva JL, Manresa D. Vigilancia de la bacteriemia nosocomial en la unidad de cuidados intensivos del Hospital Pediátrico Docente Centro Habana. Rev Cubana Med Trop 1992; 44:25-8.

64. Holzel H, Saxe M. Septicaemia in paediatric intensive-care patients at the hospital for sick children, Great Ormond Street. J Hosp Infect 1992; 22 185-95.

65. Rubenstein JS, Kabat K, Shulman ST, Yogev R. Bacterial and fungal colonization of endotracheal tubes in children: a prospective study. Crit Care Med 1992; 20:1544-9.

66. Panlilio AL, Beck-Sague CM, Siegel JD, Anderson RL, Yetts SY, Clark NC, et al. Infections and pseudoinfections due to povidone-iodine solution contaminated with Pseudomonas cepacia. Clin Infect Dis 1992; 14:1078-83.

67. Casado-Flores J, Valdivielso-Serna A, Pérez-Jurado L, Pozo-Román J, Monleón-Luque M, García-Pérez J, et al. Subclavian vein catheterization in critically ill children: analysis of 322 cannulations. Intensive Care Med 1991; 17:350-4.

68. Pollock E, Ford-Jones EL, Corey M, Barker G, Mindorff CM, Gold R, et al. Use of the paediatric risk of mortality score to predict nosocomial infection in a paediatric intensive care unit. Crit Care Med 1991; 19:160-5.

69. Beck-Sagué CM, Jarvis WR, Brook JH, Culver DH, Potts A, Gay E, et al. Epidemic bacteremia due to Acinetobacter baumannii in five intensive care units. Am J Epidemiol 1990; 132:723-33.

70. Getchell-White SI, Donowitz LG, Gröschel DH. The inanimate environment of an intensive care unit as a potential source of nosocomial bacteria: evidence for long survival of Acinetobacter calcoaceticus. Infect Control Hosp Epidemiol 1989; 10:402-7.

71. Cook PP, Hecht DW, Snydman DR. Nosocomial Branhamella catarrhalis in a paediatric intensive care unit: risk factors for disease. J Hosp Infect 1989; 13:299-07.

72. Klein BS, Perloff WH, Maki DG. Reduction of nosocomial infection during paediatric intensive care by protective isolation. N Engl J Med 1989; 320:1714-21.
73. Derkay CS, Bluestone CD, Thompson AE, Kardatske D. Otitis media in the paediatric intensive care unit: a prospective study. Otolaryngol Head Neck Surg 1989; 100:292-9.

74. Velasco-Jabalquinto MJ, Fernández-Crehuet NR, Real-Gallego I, Pérez-Navero JL, Romanos-Lezcano A. Infección hospitalaria y resistencia a antimicrobianos en una unidad de cuidados intensivos de pediatría. An Esp Pediatr 1988; 29:122-6.

75. Bhattacharyya N, Kosloske AM, Macarthur C. Nosocomial infection in paediatric surgical patients: a study of 608 infants and children. J Pediatr Surg 1993; 28:338-43.

76. Winfield JA, Rosenthal P, Kanter RK, Casella G. Duration of intracranial pressure monitoring does not predict daily risk of infectious complications. Neurosurgery 1993; 33:424-30.

77. Hiranandani M, Singhi SC, Kaur I, Chakrabarti A. Disseminated nosocomial candidiasis in a paediatric intensive care unit. Indian Pediatr 1995; 32:1160-6.

78. Correia M, Simão C, Lito LM, Cabeçadas M, Almeida H, Carvalho A, et al. Infecção nosocomial numa unidade de cuidados intensivos pediátricos. Acta Med Port 1997; 10:463-8.

79. Archibald LK, Manning ML, Bell LM, Banerjee S, Jarvis WR. Patient density, nurse-to-patient ratio and nosocomial infection risk in a paediatric cardiac intensive care unit. Pediatr Infect Dis J 1997; 16:1045-8.

80. Cosseron-Zerbib M, Roque-Afonso AM, Naas T, Durand P, Meyer L, Costa Y, et al. A control programme for MRSA (methicillin-resistant Staphylococcus aureus) containment in a paediatric intensive care unit: evaluation and impact on infections caused by other micro-organisms. J Hosp Infect 1998; 40:225-35.

81. Dagan O, Cox PN, Ford-Jones L, Ponsonby J, Bohn DJ. Nosocomial infection following cardiovascular surgery: comparison of two periods, 1987 vs. 1992. Crit Care Med 1999; 27:104-8.

82. Patel JC, Mollitt DL, Tepas JJ. Infectious complications in critically injured children. J Pediatr Surg 2000; 35:1174-8.

83. Pierce CM, Wade A, Mok Q. Heparin-bonded central venous lines reduce thrombotic and infective complications in critically ill children. Intensive Care Med 2000; 26:967-72.

84. Manning ML, Archibald LK, Bell LM, Banerjee SN, Jarvis WR. Serratia marcescens transmission in a paediatric intensive care unit: a multifactorial occurrence. Am J Infect Control 2001; 29:115-9.

85. Gray J, Gossain S, Morris K. Three-year survey of bacteremia and fungemia in a paediatric intensive care unit. Pediatr Infect Dis J 2001; 20:416-21.

86. O'Neill JM, Schutze GE, Heulitt MJ, Simpson PM, Taylor BJ. Nosocomial infections during extracorporeal membrane oxygenation. Intensive Care Med 2001; 27:1247-53.

87. Toltzis P, Rosolowski B, Salvator A. Etiology of fever and opportunities for reduction of antibiotic use in a paediatric intensive care unit. Infect Control Hosp Epidemiol 2001; 22:499-04. 
88. Yagupsky P, Sofer S, Dagan R. Early onset pneumococcal sepsis in children hospitalized for noninfectious life-threatening events. Pediatr Infect Dis J 2001; 20:1092-4.

89. Martínez-Aguilar G, Anaya-Arriaga MC, AvilaFigueroa C. Incidence of nosocomial bacteremia and pneumonia in paediatric unit. Salud Publica Mex 2001; 43:515-23.

90. Lopes JM, Tonelli E, Lamounier JA, Couto BR, Siqueira AL, Komatsuzaki F, et al. Prospective surveillance applying the national nosocomial infection surveillance methods in a Brazilian paediatric public hospital. Am J Infect Control 2002; 30:1-7.

91. Ben-Abraham R, Keller N, Szold O, Vardi A, Weinberg M, Barzilay Z, et al. Do isolation rooms reduce the rate of nosocomial infections in the paediatric intensive care unit? J Crit Care 2002; 17:176-80.

92. Einloft PR, Garcia PC, Piva JP, Bruno F, Kipper DJ, Fiori RM. Perfil epidemiológico de dezesseis anos de uma unidade de terapia intensiva pediátrica. Rev Saúde Pública 2002; 36:728-33.

93. Urrea M, Pons M, Serra M, Latorre C, Palomeque A. Prospective incidence study of nosocomial infections in a paediatric intensive care unit. Pediatr Infect Dis J 2003; 22:490-4.

94. Loukil C, Saizou C, Doit C, Bidet P, Mariani-Kurkdjian P, Aujard Y, et al. Epidemiologic investigation of Burkholderia cepacia acquisition in two paediatric intensive care units. Infect Control Hosp Epidemiol 2003; 24:707-10.

95. Bureau-Chalot F, Piednoir E, Pierrat C, Santerne B, Bajolet $\mathrm{O}$. Epidémie nosocomiale à Burkholderia cepacia dans une unité de réanimation infantile. Arch Pediatr 2003; 10:882-6.

96. Abramczyk ML, Carvalho WB, Carvalho ES, Medeiros EA. Nosocomial infection in a paediatric intensive care unit in a developing country. Braz J Infect Dis 2003; 7:375-80.

97. Arantes A, Carvalho ES, Medeiros EA, Farhat CK, Mantese OC. Uso de diagramas de controle na vigilância epidemiológica das infecções hospitalares. Rev Saúde Pública 2003; 37:768-74.

98. Tekerekoglu MS, Durmaz R, Ay S, Ciçek A, Kutlu O. Epidemiologic and clinical features of a sepsis caused by methicillin-resistant Staphylococcus epidermidis (MRSE) in a paediatric intensive care unit. Am J Infect Control 2004; 32:362-4.

99. Randolph AG, Reder L, Englund JA. Risk of bacterial infection in previously healthy respiratory syncytial virus-infected young children admitted to the intensive care unit. Pediatr Infect Dis J 2004; 23:990-4.

100. Elward AM, Hollenbeak CS, Warren DK, Fraser VJ. Attributable cost of nosocomial primary bloodstream infection in paediatric intensive care unit patients. Pediatrics 2005; 115:868-72.

101. Frank M, Gur E, Givon-Lavi N, Peled N, Dagan R, Leibovitz E. Nosocomial bloodstream infections in children and adolescents in southern Israel: a 10-year prospective study (1992-2001). Scand J Infect Dis 2005; 37:177-83.

102. Carvalho CE, Berezin EN, Pistelli IP, Mímica L, Cardoso MR. Monitoramento microbiológico seqüencial da secreção traqueal em pacientes intubados internados em unidade de terapia intensiva pediátrica. J Pediatr (Rio J.) 2005; 81:29-33.
103. Peterlini MAS, Pedreira MLG, Harada MJSC, Pereira SR, Chaud MN, Carvalho WB. Cateter de bulbo da jugular: tempo de permanência, motivo da retirada e colonização. Acta Paul Enferm 1999; 12:32-40.

104. Caffarone D, Olazarri F, Moreno E, Nieva A, Rivas N. Infecciones diseminadas por Candida albicans en una unidad de cuidados intensivos pediátrica. Med Intensiva 1994; 11:13-20.

105. Narvaez GA, Paz VS, Ribeiro MAS, Lopes MV, Pitrez Filho MLS, Berquó L, et al. Infecções hospitalares em pediatria: a realidade de um hospital universitário. Arq Bras Med 1991; 65:104S.

106. Ducharme FM. Incidence of infection related to arterial catheterization in children: a prospective study. Crit Care Med 1988; 16:272-6.

107. Elward AM. Paediatric ventilator-associated pneumonia. Pediatr Infect Dis J 2003; 22:445-6.

108. Moreira CBA. Estudo da Incidência e dos fatores de risco das infecções hospitalares da unidade de terapia intensiva pediátrica do Hospital Universitário Regional do Norte do Paraná, Londrina, PR [Dissertação de Mestrado]. Londrina: Universidade Estadual de Londrina; 2003.

109. Abramczyk ML. Infecção hospitalar em unidade de terapia intensiva pediátrica de hospital universitário de São Paulo [Dissertação de Mestrado]. São Paulo: Universidade Federal de São Paulo; 2000 .

110. Ben Jaballah N, Bouziri A, Kchaou W, Hamdi A, Mnif K, Belhadj S, et al. Epidémiologie des infections bactériennes nosocomiales dans une unité de réanimation néonatale et pédiatrique tunisienne. Med Mal Infect 2006; 36:379-85.

111. Wells GA, Shea B, O'Connell D, Peterson J, Welch V, Losos M, et al. The Newcastle-Ottawa Scale (NOS) for assessing the quality of nonrandomised studies in meta-analyses. Ottawa Health Research Institute http://www.ohri.ca/ programs/clinical_epidemiology/oxford.htm (accessed on 26/Jul/2004).

112. Downs SH, Black N. The feasibility of creating a checklist for the assessment of the methodological quality both of randomised and non-randomised studies of health care interventions. J Epidemiol Community Health 1998; 52:377-84.

113. Katrak P, Bialocerkowski AE, Massy-Westropp N, Kumar S, Grimmer KA. A systematic review of the content of critical appraisal tools. BMC Med Res Methodol 2004; 4:22.

114. Ford-Jones EL, Mindorff CM, Langley JM, Allen U, Nàvàs L, Patrick ML, et al. Epidemiologic study of 4684 hospital-acquired infections in paediatric patients. Pediatr Infect Dis J 1989; 8:668-75.

115. Allen U, Ford-Jones EL. Nosocomial infections in the paediatric patient: an update. Am J Infect Control 1990; 18:176-93.

116. Institute for Healthcare Improvement. Campaign highlights. http://www.ihi.org/IHI/Programs/ Campaign/ (accessed on 10/Aug/2005).

117. Lee OKE, Johnston L. A systematic review for effective management of central venous catheters and catheter sites in acute care paediatric patients. Worldviews on evidence-based. Nursing 2005; 2:4-13. 
118. Rowin ME, Patel VV, Christenson JC. Paediatric intensive care unit nosocomial infections: epidemiology, sources and solutions. Crit Care Clin 2003; 19:473-87.

119. Shah SS, Smith MJ, Zaoutis TE. Device-related infections in children. Pediatr Clin North Am 2005; 52:1189-208.

120. Institute for Healthcare Improvement. Overview of the 5 million lives campaign. http://www. ihi.org/IHI/Programs/Campaign/Campaign. htm?TabId=1 (accessed on 10/Aug/2007).

121. Centers for Disease Control and Prevention. National Nosocomial Infections Surveillance (NNIS) system report, data summary from January 1992 to June 2004, issued August 2004. Am J Infect Control 2004; 32:470-85.

122. Horan TC, Gaynes RP. Surveillance of nosocomial infections. In: Mayhall CG, editor. Hospital epidemiology and infection control. 3rd Ed. Philadelphia: Lippincott Williams \& Wilkins; 2004. p. 1659-62.
123. Collard HR, Saint S, Matthay MA. Prevention of ventilator-associated pneumonia: an evidencebased systematic review. Ann Intern Med 2003; 138:494-501.

124. Epps B, Edwards JR, Sohn AH, Horan TC, Gaynes RP. Improving benchmarks for surveillance by defining types of paediatric intensive care units. Am J Infect Control 2002; 30:68-70.

125. Langley JM, Bradley JS. Defining pneumonia in critically ill infants and children. Pediatr Crit Care Med 2005; 6(3 Suppl):S9-13.

126. Langley JM. Defining urinary tract infection in the critically ill child. Pediatr Crit Care Med 2005; 6(3 Suppl):S25-9.

127. Fischer JE. Physicians' ability to diagnose sepsis in newborns and critically ill children. Pediatr Crit Care Med 2005; 6(3 Suppl):S120-5.

Submitted on $05 / \mathrm{Jan} / 2009$

Final version resubmitted on 02/May/2009

Approved on 22/Jun/2009 